This is an author accepted manuscript of a paper that can be cited as: Rolo, V., Hartel, T., Aviron, S., Berg, S., Crous-Duran, J., Franca, A., Mirck, J., Palma, J.H.N., Pantera, A., Paulo, J.A., Pulido, F.J., Seddaiu, G., Thenail, C., Varga, A., Viaud, V., Burgess, P.J., Moreno, G. (2020). Challenges and innovations for improving the resilience of European agroforestry systems of high nature and cultural value: a stakeholder perspective. Sustainability Science. https://doi.org/10.1007/s11625020-00826-6

\title{
Challenges and innovations for improving the sustainability of European agroforestry systems of high nature and cultural value: stakeholder perspectives
}

Rolo $\mathrm{V}^{1}$, Hartel $\mathrm{T}^{2}$, Aviron $\mathrm{S}^{3}$, Berg $\mathrm{S}^{4}$, Crous-Duran $\mathrm{J}^{5}$, Franca $\mathrm{A}^{6}$, Mirck $\mathrm{J}^{7}$, Palma $\mathrm{JHN}^{5,12}$, Pantera $\mathrm{A}^{8}$, Paulo $\mathrm{JA}^{5}$, Pulido $\mathrm{FJ}^{1}$, Seddaiu $\mathrm{G}^{9}$, Thenail $\mathrm{C}^{3}$, Varga $\mathrm{A}^{11}$, Viaud $\mathrm{V}^{13}$, Burgess $\mathrm{PJ}^{10}$, Moreno $\mathrm{G}^{1}$

${ }^{1}$ Institute for Dehesa Research (INDEHESA), University of Extremadura, Plasencia 10600, Spain. Corresponding author: gmoreno@unex.es

${ }^{2}$ Babes-Bolyai University, Hungarian Department of Biology and Ecology, Str. Clinicilor 5-7, Romania

${ }^{3}$ INRAE, UMR 980 BAGAP, 65 Rue de Saint Brieuc, CS 84215, 35042 Rennes, France

${ }^{4}$ The European Forest institute, Joensuu, Finland

${ }^{5}$ Forest Research Centre, School of Agriculture, University of Lisbon, Tapada da Ajuda, 1349-017 Lisboa, Portugal

${ }^{6}$ CNR-ISPAAM, Trav. La Crucca 3, Reg. Baldinca, Sassari 07100, Italy

${ }^{7}$ EntoNative $\mathrm{GmbH}, 14558$ Potsdam-Rehbrücke, Germany

${ }^{8}$ Dpt. of Forestry \& N.E.M., Agricultural University of Athens, 36100, Greece

${ }^{9}$ Nucleo Ricerca Desertificazione, University of Sassari, Sassari 07100, Italy

${ }^{10}$ School of Water, Energy and Environment, Cranfield University, Cranfield, Bedfordshire, UK

${ }^{11}$ MTA Centre for Ecological Research, Alkotmány u. 2-4, 2163, Vácrátót, Hungary

${ }^{12}$ MV Agroecology Research Centre, Moinhos de Vento, Mértola, 7750-217 Espírito Santo, Portugal

${ }^{13}$ INRAE, UMR 1069 SAS, 65 Rue de Saint Brieuc, CS 84215, 35042 Rennes, France

\begin{abstract}
Traditional forms of agroforestry are often recognized as exemplar systems that successfully integrate food production, biodiversity conservation and high cultural values. However many traditional agroforestry systems in Europe are in decline or are threatened and the perspectives of local stakeholders on the production, management, socio-economic, and environmental dimensions of such systems are not fully understood. In order to fill this gap, we present results of participatory research performed with ten stakeholder groups (SG) across Europe to search for solutions to improve the economic and ecological sustainability of High Nature and Cultural Value agroforestry systems (HNCV agroforestry). Stakeholders included both users and beneficiaries of the HNCV agroforestry. First, SGs held open discussions (227 participants) to identify major challenges for the long-term sustainability of HNCV agroforestry. Challenges were classified into production, management, socioeconomic and the environment categories. Second, they responded to structured questionnaires (120 respondents) that explored the positive and negative perceptions of 45 possible attributes of HNCV
\end{abstract}


agroforestry. Third, innovative solutions were identified by individual and group discussions to address the four categories of challenge. Challenges were mostly identified for the management and socioeconomic categories, but several challenges concerning production and environment were also pinpointed. Besides, solutions matched poorly with the challenges identified, and, while challenges were at some extent common across countries, solutions to address them were more case-specific. The successful implementation of these solutions requires an in-depth understanding of the diversity of socio-cultural and natural contexts of the HNCV agroforestry systems and building bottom-up proposals and collective actions based on this understanding. The sustainability of HNCV agroforestry would benefit from providing farmers and managers with a financial advantage from the high nature and cultural value of these systems.

\section{Keywords}

Adaptive policy; European survey; Mosaic-like agriculture; Participative innovation; Regional-based solution; Silvopastoral systems.

\section{Introduction}

High Nature Value (HNV) farmland has been defined in relation to three criteria: i) the presence of agriculture as the major land use, ii) high biodiversity, and iii) the presence of semi-natural vegetation and features (Andersen et al. 2003). Many of the HNV farms in Europe include silvopastoral agroforestry systems comprising trees interspersed by grassland grazed by livestock. Examples of such systems include wood-pastures, grazed woodlands, fodder-tree systems and meadows with pollarded trees. Mosaics of small-scale crop fields intermixed with hedges, tree lines and small woods have also been recognised for their high nature value (Parachinni et al. 2008). Such mosaics can also be considered as agroforestry where the fields of grass and arable crops have significant ecological and economic interactions with the woody vegetation components.

The biophysical, natural and economic features of traditional European agroforestry systems are shaped by human culture, value systems, knowledge types and the bioclimatic setting. In other words, for centuries, people have moulded these systems through their activities and these systems have delivered a variety of ecosystem services to people (Lomba et al. 2020). Since the rich natural and socio-cultural values of traditional European agroforestry systems are inextricably linked (Hartel and Plieninger 2014), these systems are often referred as High Natural and Cultural Value agroforestry systems (hereafter HNCV agroforestry, Moreno et al. 2018).

Different types of HNCV agroforestry occurs throughout Europe and these have been described in several recent papers (e.g. Bignal and McCracken 2000; Bergmeier et al. 2010; Plieninger et al. 2015; Moreno et al. 2018). Wood pastures, grazed woodlands, and meadows and farming mosaics rich in hedgerows are common HNCV agroforestry in Europe (Moreno et al. 2018). While many woodpastures in Mediterranean and Eastern Europe are still grazed and continue to form an integral part of farm businesses (Moreno et al 2018; Hartel et al. 2013; den Herder et al. 2017), in the lowlands of central and northern parts of Europe, wood-pastures are often managed for nature conservation purposes (Butler et al 2002). Hedgerow-rich farming landscapes are common in the UK, North-West 
France (named bocage) and parts of Central Europe (e.g. Spreewald in Germany), but in many areas farm intensification has reduced the length and quality of hedgerows. In Scandinavian countries, reindeer husbandry is an extensive agroforestry system that occurs alongside other land uses such as forestry, hunting, and tourism (Valinger et al. 2018).

HNCV agroforestry can provide outputs such as wood, crop, livestock and game products, and services such as high biodiversity and opportunities for recreational and cultural interactions (Calama et al. 2010). Other services include carbon sequestration, nutrient retention, microclimate moderation, control of air and water pollution and soil erosion, pollination, and biological pest control (Jose et al. 2009; Torralba et al. 2016; Kay et al. 2019). HNCV agroforestry was recently highlighted as archetypical example of a landscape which works for biodiversity and people (Kremen and Merenlender 2018). However, social, economic and environmental change is threatening the sustainability of much of the HNCV agroforestry in Europe. Economic pressures can drive farmers to specialize and intensify production often leading to simpler farming systems and greater use of external inputs (Mannig et al. 2006), often leading in the long-term to progressive soil degradation, and the loss of trees, habitat and biological diversity (Plieninger and Wilbrand 2001; Pereira and Domingo 2004; Moreno and Pulido 2009). Conversely livestock farming can be abandoned (Pulido et al. 2010; Pantera et al. 2018a; Rossetti et al. 2014; Paulo et al. 2015; Aubard et al. 2019), resulting in woody vegetation encroachment (Archer 2010), with can affect the function and productivity of the land (Eldridge et al. 2011; Bugalho et al. 2011; Gómez-Rey, 2013; Faias et al. 2018). Such interactions demonstrate that HNCV agroforestry creates complex social-ecological systems that include numerous productive, ecological and cultural trade-offs (Torralba et al 2018). One way to better achieve desired regional and national goals and targets is to incorporate stakeholders' perceptions and values and involve stakeholders in decision-making processes, plans and efforts (Villamor et al. 2014).

In this research we provide the first comprehensive European overview of the challenges that face sustainable agroforestry as they are perceived by different stakeholder groups specifically focused on HNCV agroforestry. To understand these aspects we relied on the expertise and perceptions of a wide range of stakeholders, all closely linked to agroforestry systems, including farmers, environment NGOs, businesses, private and public technical staff, researchers and policy makers, operating between local and national scales. Our study covers all the major HNCV agroforestry regions and types of Europe, from East to West and from South to North. We identified the main challenges and possible solutions that could be implemented at the field, farm- and landscape scales in order to improve the ecological and socio-economic sustainability of HNCV agroforestry. This approach ensured that local effectiveness and European scale relevance were aligned.

\section{Methods}

\section{Systems selection and description}

We selected ten representative examples of HNCV agroforestry across five European bioclimatic regions (Mediterranean, Atlantic, Continental, Pannonian and Boreal). The examples include the main types of HNCV agroforestry found in Europe, namely grazed woodlands, wood-pastures, and agricultural mosaics rich in hedgerows (Table 1). Although the ten systems selected varied in terms of system structure, farming activities, and ecological and socio-economic contexts, they all provided a 
range of private and public ecosystem services, had high socio-cultural values and faced socioeconomic challenges. A full description of the systems is provided by Moreno et al. (2018).

\section{Stakeholder groups}

In each country a stakeholder group (SG) was created in 2014 (Burgess and Rosati 2018). The number of stakeholders ranged from 5 (Romanian and British SGs) to 80 (Spanish SG) stakeholders, with a total of 227 for the ten countries (Table 1). These included both users and beneficiaries of the HNCV agroforestry systems: farmers, breeders, foresters, agronomists, landowners, regional and national famer associations, agricultural service companies, extension services, environmental NGOs, local action groups, representatives of local administration, consumers and policy makers and scientists. Many of the organization representatives operated at a regional scale, having direct experience in working with farmers as well as decision makers.

\section{Data compilation}

Stakeholder perceptions were derived from a series of workshops with a common design, that have been described in previous work examining stakeholder perception of the sustainability of agroforestry in Europe (García de Jalón et al., 2018; Hernández-Morcillo et al., 2018). However this study focuses solely on HNCV agroforestry. Each stakeholder group held up to three meetings, with an open discussion to identify and prioritize the main challenges faced by farmers in relation to HNCV agroforestry.

Some stakeholders $(n=120)$ also completed a structured questionnaire to rank a list of 45 issues related to either the production (9), environment (11), management (8) or socioeconomic (17) aspects of HNCV agroforestry (Supplementary Table S1). Each respondent first selected and prioritized up to 10 aspects that were the most positive attribute of HNCV agroforestry, ranking them from 1 (highest) to 10 within each of the four categories. Similarly, respondents also selected and prioritized up to 10 aspects that were the most negative attribute of HNCV agroforestry. In a final step, stakeholders worked either individually or in group discussion to identify and select possible innovative solutions to address the opportunities and challenges highlighted by the preceding discussions.

Working with the structured questionnaires, García-Jalón et al. (2018) identified positive and negative perceptions of agroforestry systems, whereas the work conducted by Hernández-Morcillo et al. (2018) was based on the open discussions and focused on the main challenges that affect agroforestry and the proposed innovative solutions. Our work takes these further by integrating both types of data (structured questionnaires and open discussions) to provide a comprehensive overview of interrelationships between perceptions, challenges and solutions disaggregated the local level. We believe that the degree of coherence between the different approaches might indicate the opportunity to achieve sustainability. In other words, a sustainable system might show a good agreement between its perception, the number of challenges and proposed solutions. 
Table 1. Characteristics of the ten stakeholder groups that participate in the discussion meeting and the number of respondents that responded to the structured questionnaires.

\begin{tabular}{|c|c|c|c|c|c|}
\hline Country & $\begin{array}{l}\text { Agroforestry } \\
\text { systems }\end{array}$ & Stakeholders types & $\begin{array}{l}\text { Number of } \\
\text { attendees }\end{array}$ & $\begin{array}{c}\text { Number of } \\
\text { respondents }\end{array}$ & Main concerns verbalized \\
\hline Portugal & $\begin{array}{l}\text { Montado (grazed } \\
\text { oak pastures) }\end{array}$ & $\begin{array}{l}\text { technical advisors, farm } \\
\text { managers, forest } \\
\text { managers, } \\
\text { representatives of farm } \\
\text { and forest managers and } \\
\text { public institutions }\end{array}$ & 22 & 17 & $\begin{array}{l}\text { Negative consequences of } \\
\text { shrub encroachment of cork } \\
\text { oak woodlands for cork yield } \\
\text { and quality }\end{array}$ \\
\hline Spain & $\begin{array}{l}\text { Dehesa (grazed } \\
\text { oak pastures) }\end{array}$ & $\begin{array}{l}\text { farmers (livestock } \\
\text { breeders), landowners, } \\
\text { technical advisors, } \\
\text { agrarian administrators, } \\
\text { environmentalists, } \\
\text { journalists }\end{array}$ & 80 & 67 & $\begin{array}{l}\text { Low profitability, marked } \\
\text { seasonality of fodder resources } \\
\text { and deficient tree regeneration }\end{array}$ \\
\hline Italy & $\begin{array}{l}\text { Grazed oak } \\
\text { woodlands in } \\
\text { Sardinia }\end{array}$ & $\begin{array}{l}\text { Farmers, technical } \\
\text { advisors, representative } \\
\text { of agriculture and forest } \\
\text { administration }\end{array}$ & 15 & 1 & $\begin{array}{l}\text { The lack of forage availability } \\
\text { and quality }\end{array}$ \\
\hline Greece & $\begin{array}{l}\text { Valonia oak } \\
\text { silvopastoral } \\
\text { systems }\end{array}$ & $\begin{array}{l}\text { Farmers (livestock } \\
\text { breeder), agronomy } \\
\text { student, representatives } \\
\text { of municipality }\end{array}$ & 25 & 11 & $\begin{array}{l}\text { Oak regeneration and poor } \\
\text { pasture understory } \\
\text { yield/quality }\end{array}$ \\
\hline France & $\begin{array}{l}\text { Bocage } \\
\text { agroforestry in } \\
\text { Brittany }\end{array}$ & $\begin{array}{l}\text { Farmers, engineer of } \\
\text { decentralized State } \\
\text { services, technician of a } \\
\text { local administration }\end{array}$ & 42 & 13 & $\begin{array}{l}\text { Decrease of hedgerow density } \\
\text { and their reduced importance } \\
\text { in farming management and } \\
\text { ecological services }\end{array}$ \\
\hline UK & $\begin{array}{l}\text { Wood-pasture } \\
\text { and parkland }\end{array}$ & $\begin{array}{l}\text { Estate managers, } \\
\text { advisors, ecologist }\end{array}$ & 10 & 5 & $\begin{array}{l}\text { Re-instituting tree } \\
\text { management, balancing the } \\
\text { prevention of wood-pasture } \\
\text { infilling with sufficient natural } \\
\text { regeneration }\end{array}$ \\
\hline Germany & $\begin{array}{l}\text { Spreewald flood } \\
\text { plain }\end{array}$ & $\begin{array}{l}\text { Farmers, representative } \\
\text { of district administration }\end{array}$ & 5 & 2 & $\begin{array}{l}\text { Hedgerows abandonment } \\
\text { Lack of profit from trees } \\
\text { reducing the interest of } \\
\text { farmers } \\
\text { Flooding resulting in tree } \\
\text { dieback }\end{array}$ \\
\hline Romania & $\begin{array}{l}\text { Wood-pastures in } \\
\text { Southern } \\
\text { Transylvania }\end{array}$ & $\begin{array}{l}\text { Farmers, } \\
\text { Environment NGO }\end{array}$ & 5 & 0 & $\begin{array}{l}\text { Conservation of large/old } \\
\text { trees } \\
\text { Need of economically and } \\
\text { socially viable strategies to } \\
\text { increase tree regeneration } \\
\text { Control overgrazing } \\
\text { Reintroduction of the } \\
\text { traditional livestock }\end{array}$ \\
\hline Hungary & Wood-pasture & $\begin{array}{l}\text { Farmers, livestock } \\
\text { breeders, manager of } \\
\text { major conservation } \\
\text { district of national park }\end{array}$ & 17 & 16 & $\begin{array}{l}\text { Infilling of abandoned wood- } \\
\text { pastures, and lack of public } \\
\text { awareness of their nature and } \\
\text { cultural values }\end{array}$ \\
\hline Sweden & $\begin{array}{l}\text { Wood-pastures } \\
\text { and reindeer }\end{array}$ & $\begin{array}{l}\text { Njaarke Sami members } \\
\text { (farmers), forest owners }\end{array}$ & 7 & 3 & $\begin{array}{l}\text { Adaptation of forest operations } \\
\text { to reindeer husbandry }\end{array}$ \\
\hline Total & & & 227 & 135 & \\
\hline
\end{tabular}




\section{Data Management}

Scores given by respondents to the structured questionnaire were computed and normalized to the scale between 100 and -100 , where 100 is the score when an issue was prioritized as the most positive by all the respondents, and -100 is the score when the issue was perceived as the most negative attribute by all. Briefly, individual scores were summed and divided by 1200 (maximum value if the 120 respondents prioritize the same issue) and then multiplied by 100 . Scores related to the positive or negative perception of issues were depicted in a scatterplot to highlight potential associations among categories (Environment, Management, Production and Socio-Economic) and their rank within each type of perception.

Collated data on the challenges found in the open discussions were initially examined in three ways for each category: i) the total number of challenges found in each stakeholder group, ii) the number of stakeholder groups where the challenge was identified, and iii) the proportion of challenges found in each stakeholder group with respect to the total number of challenges found among stakeholder groups. Finally, counts were made of those solutions, within each stakeholder groups and category, which were considered as "cost-effective for farmers" were counted within each stakeholder group and category.

\section{Results}

\section{Stakeholders' perception of agroforestry: structured questionnaire}

In total, 120 out of the 227 stakeholders completed the structured questionnaire related to HNVC agroforestry. Many of the most positively rated attributes were related to the improvement of the environment by agroforestry, such as the enhancement of biodiversity and wildlife habitats, landscape aesthetics, soil conservation, carbon sequestration and climate variation buffering (Figure 1; Supplementary Table S1). Positive production attributes included animal welfare, tree regeneration, and animal production. Positive management attributes included the originality and interest of the system, and the most positive socio-economic attributes included farmer image and tourism. The most negative attributes were generally related to the management and socio-economic category such as the increased administrative burden, issues related to subsidy and grant eligibility, difficulties for mechanization, inheritance and tax, low cash flows, labour costs, and the need for multiple skills.

\section{Challenges prioritized by stakeholders: open discussion}

Across the open discussions held by the ten stakeholder groups, nine main themes emerged regarding the challenges of HNCV agroforestry sustainability: i) forage resources (quality and production), ii) animal production, iii) system design and management, iv) tree protection and regeneration, v) grazing schemes and cost-efficient herding, vi) nature conservation, vii) farm profitability, viii) extension, and ix) administration policy and governance. Figure 2 shows for each stakeholder group (SG) the relative importance of the challenges grouped into the same four categories of the structured questionnaire (environment, management, production and socio-economy; Table 2). There were relatively high proportions of socio-economic and management challenges identified by the SGs in Germany, Greece, Hungary, Portugal and the UK. Relatively high proportions of environmental challenges were identified by the SGs in France, Hungary, Italy, Romania and the UK, and the highest proportion of productivity related challenges were identified by the Spanish and Swedish SGs. 


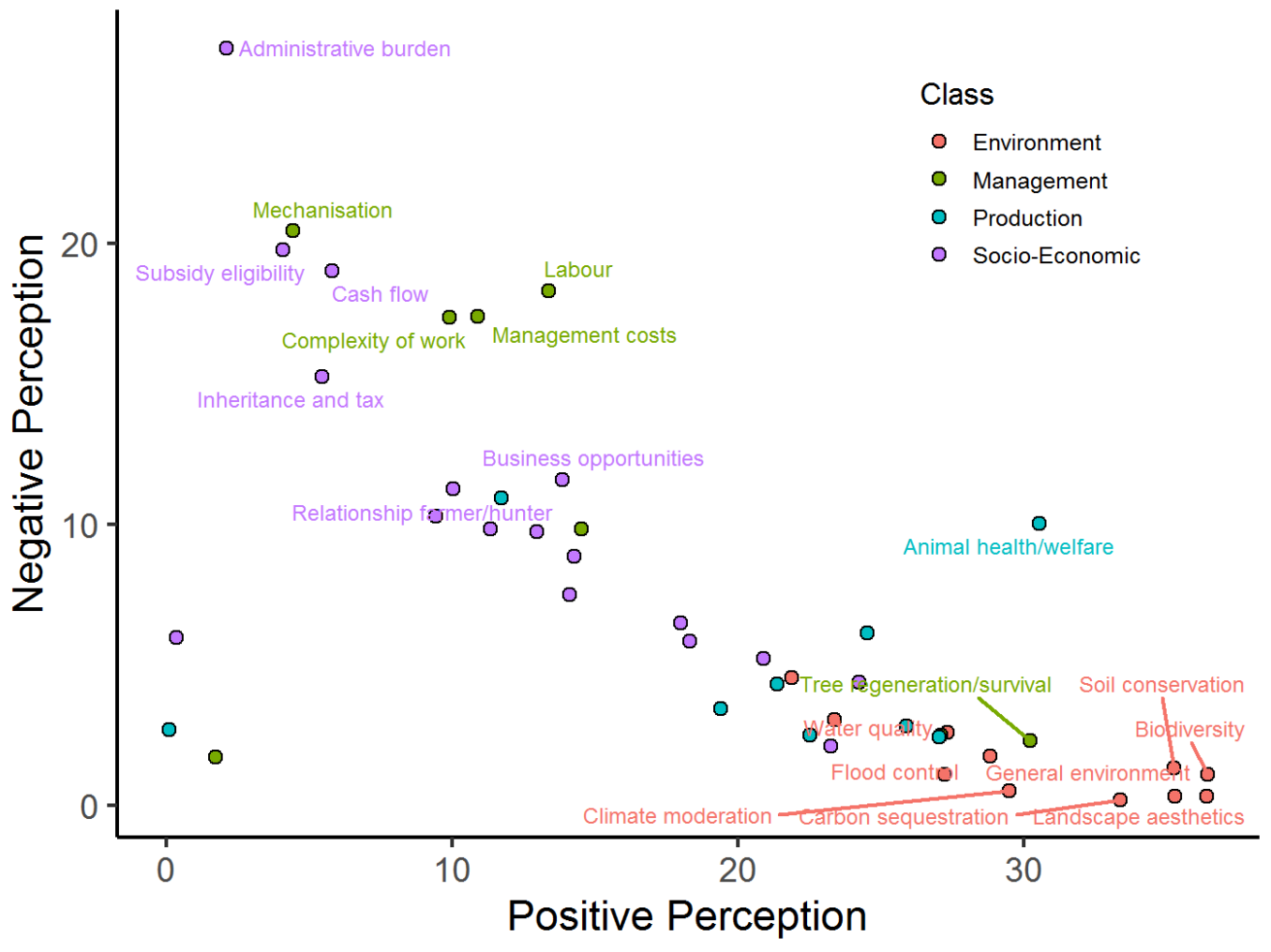

Figure 1. Relationship between positive and negative scores assigned by stakeholders during the structured questionnaire. Issues scored were grouped into four classes
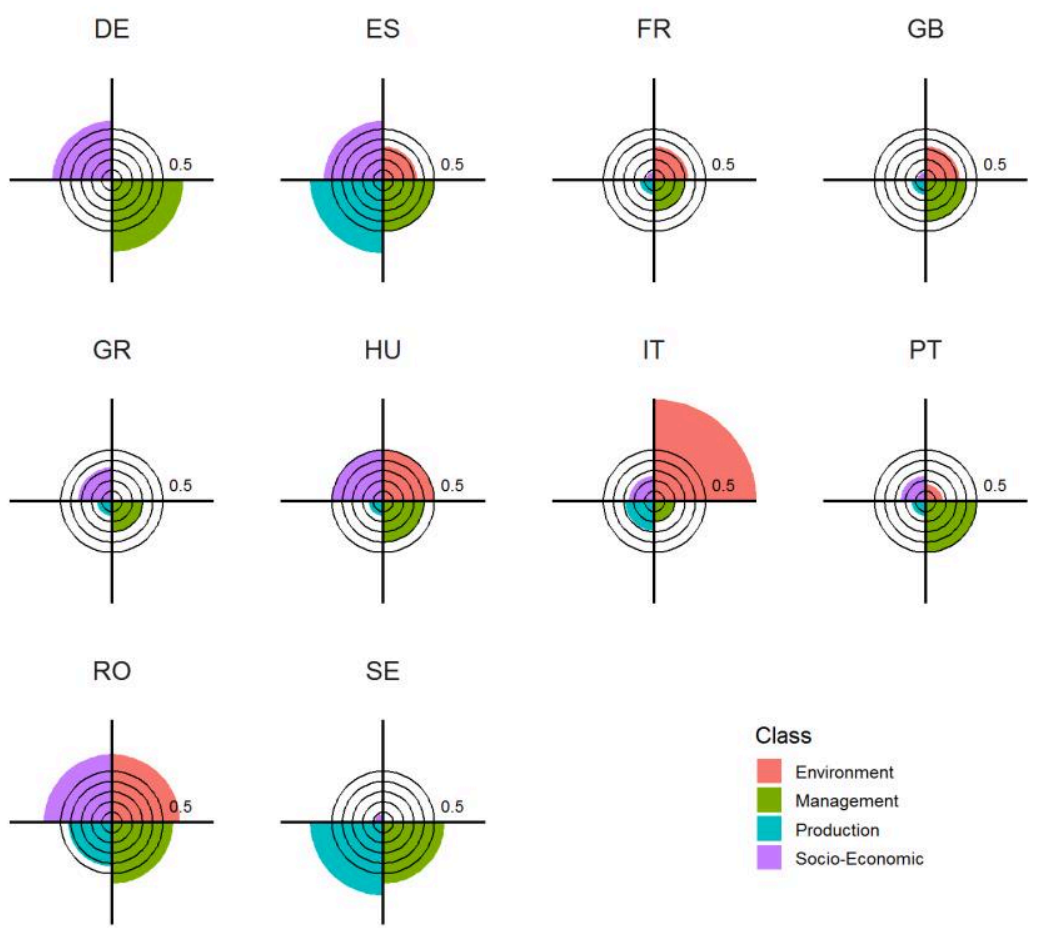

Figure 2. Proportion of challenges identified for each country grouped into four classes 
Table 2. Summary of stratified challenges identified by stakeholder groups in ten European countries, and grouped into four categories and nine themes

\begin{tabular}{|c|c|c|c|}
\hline Categories & Themes & Challenges & Stakeholder Groups \\
\hline \multirow[t]{7}{*}{ Production } & \multirow{3}{*}{$\begin{array}{l}\text { Pasture quality / } \\
\text { fodder autonomy }\end{array}$} & Overcome strong seasonality of "natural" forage & $\mathrm{ES}, \mathrm{HU}, \mathrm{SE}$ \\
\hline & & Increase pasture productivity and quality & $E S, I T, R O, S E$ \\
\hline & & Restoration of degraded pastures / disturbed areas & SE \\
\hline & \multirow[t]{4}{*}{ Animal production } & $\begin{array}{l}\text { Genetic selection. Docility \& Browsing behaviour. Local } \\
\text { races }\end{array}$ & ES, UK \\
\hline & & Diversification (Geese, Turkeys, Red Deer ...) & ES \\
\hline & & $\begin{array}{l}\text { Livestock Health (water quality, reinfection from wild } \\
\text { fauna, sheltering ...) }\end{array}$ & $P T, E S, G R, R O, F R, S E$ \\
\hline & & Control of Predators/wildlife animals & IT, RO, SE \\
\hline \multirow[t]{10}{*}{ Management } & \multirow[t]{4}{*}{$\begin{array}{l}\text { System design \& } \\
\text { management }\end{array}$} & $\begin{array}{l}\text { Design and management of the systems to (new) } \\
\text { multiple purposes. Synergies among three components } \\
\text { (tree, pasture and livestock). Adaptive design of } \\
\text { hedgerows }\end{array}$ & $I T, D E, F R, S E$ \\
\hline & & $\begin{array}{l}\text { Tree layer management. Three dimensional design and } \\
\text { management (layers, width, connections) }\end{array}$ & $\mathrm{PT}, \mathrm{GR}, \mathrm{RO}, \mathrm{HU}, \mathrm{DE}, \mathrm{FR}, \mathrm{SE}$ \\
\hline & & Livestock management & $\mathrm{PT}, \mathrm{IT}, \mathrm{RO}, \mathrm{DE}, \mathrm{SE}$ \\
\hline & & Infrastructures for livestock transport. Transhumance & IT, SE \\
\hline & \multirow{3}{*}{$\begin{array}{l}\text { Tree protection \& } \\
\text { regeneration }\end{array}$} & Reconciling grazing with trees (cost-efficient protectors) & $\mathrm{PT}, \mathrm{GR}, \mathrm{RO}, \mathrm{HU}, \mathrm{DE}, \mathrm{UK}$ \\
\hline & & Tree species diversity. Native species & PT, RO, HU, DE, FR, SE \\
\hline & & Tree decay (pests, diseases and wildfire), and fruit losses & $\mathrm{PT}, \mathrm{ES}, \mathrm{DE}, \mathrm{UK}$ \\
\hline & \multirow{3}{*}{$\begin{array}{l}\text { Grazing schemes } \\
\text { and cost-efficient } \\
\text { herding }\end{array}$} & $\begin{array}{l}\text { More efficient and even use of extensive forage } \\
\text { resources }\end{array}$ & $E S, G R, R O, D E$ \\
\hline & & Livestock species & RO, UK \\
\hline & & Cost-efficient herding. Technology & ES, HU, UK, SE \\
\hline \multirow[t]{6}{*}{ Environment } & \multirow[t]{6}{*}{$\begin{array}{l}\text { Nature } \\
\text { conservation }\end{array}$} & $\begin{array}{l}\text { Soil Protection. Stocking rate matching to forage } \\
\text { resources and soil capacities. }\end{array}$ & PT, ES, IT, FR \\
\hline & & Organic matter and Soil carbon Sequestration & ES, IT, UK \\
\hline & & Fire Control & $\mathrm{IT}, \mathrm{RO}$ \\
\hline & & Cultural landscapes & IT, RO, HU \\
\hline & & Protection of ancient trees & IT, RO, HU \\
\hline & & Biodiversity conservation & IT, RO, HU, FR, UK \\
\hline \multirow{16}{*}{$\begin{array}{l}\text { Socio- } \\
\text { Economic }\end{array}$} & \multirow[t]{7}{*}{ Farm profitability } & Branding HNCV agroforestry product. Trademark & $\mathrm{ES}, \mathrm{GR}, \mathrm{RO}, \mathrm{HU}, \mathrm{DE}, \mathrm{UK}$ \\
\hline & & Product diversification. New products & Es, GR, RO \\
\hline & & Halt abandonment & $\mathrm{GR}, \mathrm{RO}, \mathrm{DE}$ \\
\hline & & Access to tree products & $H U, D E$ \\
\hline & & $\begin{array}{l}\text { Quality of tree products (e.g. cork quality vs } \\
\text { management) }\end{array}$ & PT \\
\hline & & Green Accounting System. & PT, ES, DE \\
\hline & & Economical Evaluation of ES \& Ecological footprint & \\
\hline & \multirow[t]{3}{*}{ Extension } & Public research centre & ES \\
\hline & & Maintenance of local knowledge & PT, ES, RO, FR \\
\hline & & Encouraging local state officials in extension activities & PT, GR, FR \\
\hline & \multirow[t]{6}{*}{$\begin{array}{l}\text { Policy and } \\
\text { governance }\end{array}$} & $\begin{array}{l}\text { Specific Measures \& Grants (CAP). Long Term } \\
\text { Regulations. Comprehensive }\end{array}$ & $\mathrm{PT}, \mathrm{IT}, \mathrm{GR}, \mathrm{HU}, \mathrm{DE}, \mathrm{FR}$ \\
\hline & & Support to extensive pastoralism & ES, IT, RO \\
\hline & & Social Participation. Operational groups. & ES, IT, RO, HU, DE \\
\hline & & Public / Communal pastures & RO \\
\hline & & Associationism & $\mathrm{ES}, \mathrm{RO}, \mathrm{HU}$ \\
\hline & & Land ownership. Grazing allowed & RO, HU, DE, SE \\
\hline
\end{tabular}


In total, 16 common challenges were identified across the SGs (Figure 3; see also Tables S2 for details by SG). Eight challenges were related to management, four to socio-economic issues, and two each to production and the environment. Under the management category, the management of the tree layer and the need to reconcile grazing livestock with tree regeneration in HNCV agroforestry were common challenges. The need to improve system design and management (including the use of local breeds and practices) was seen as a challenge by most of the groups. Some of the stakeholders also expressed the willingness to use but at the same time the lack of cost-effective technologies that ease livestock management.

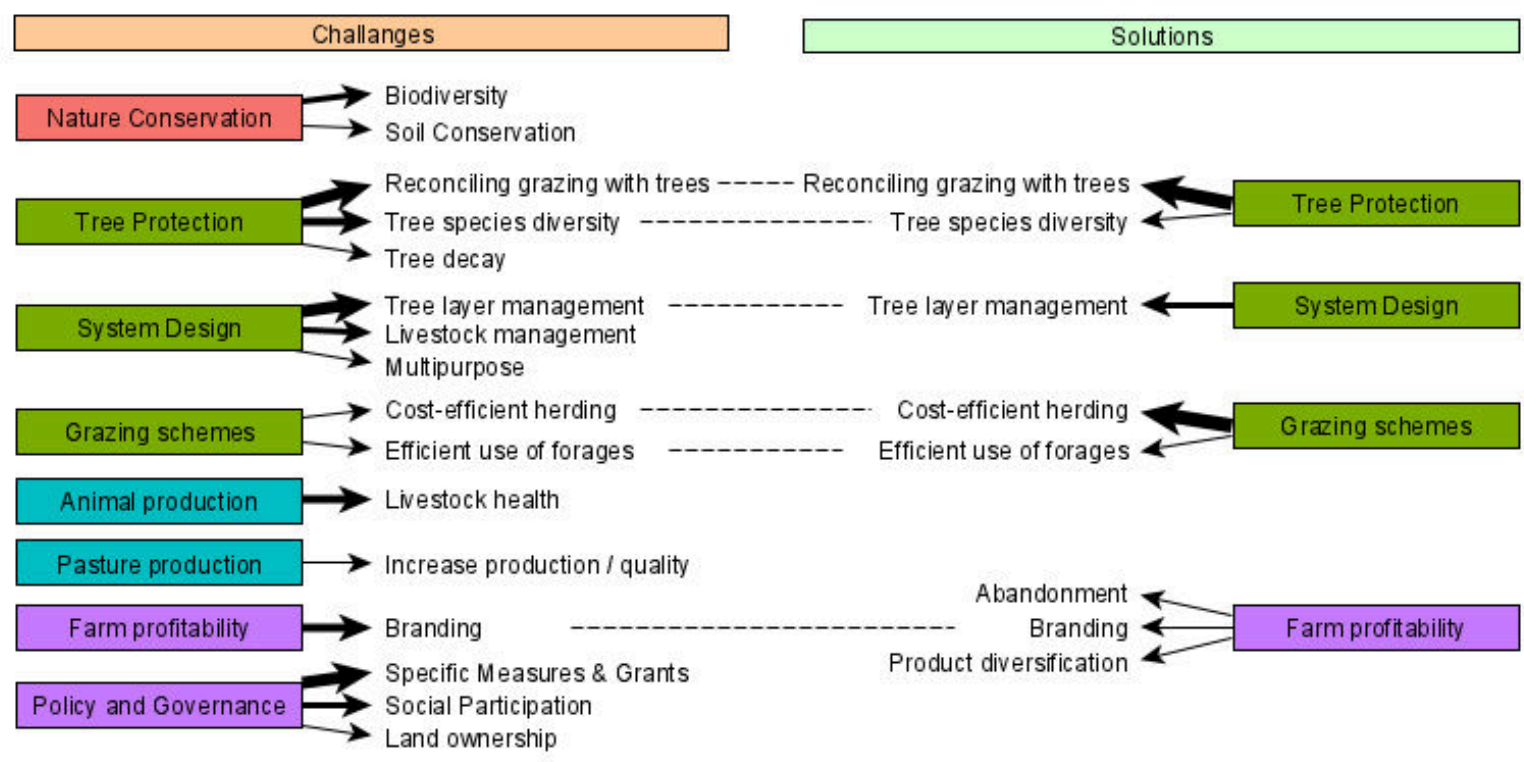

Figure 3. Match-finding between challenges and solutions identified by stakeholders in at least four countries. Arrow width depict the relative importance of the challenge (number of countries where the challenge was identified) or solution (number of solutions proposed).

Within the socio-economic category there was a general perception of the need to increase the public acknowledgment of ecosystem services and the cultural value provided by HNCV agroforestry. The lack of effective agricultural extension services in relation to agroforestry was seen as critical by four groups. Poor policy measures for HNCV agroforestry, such as illegibility for single farm payments above a certain tree density was identified by most SGs. In some countries, such as Hungary, the total legal exclusion of grazing in woodlands was a challenge.

In terms of production-related challenges, the Spanish, Italian, Romanian, Hungarian and Swedish SGs highlighted the need for increasing on-farm forage production and quality in order to improve farm self-sufficiency. The Portuguese, Spanish, Greek, Romanian, French, and Swedish SGs also highlighted the challenge concerning livestock-wildlife conflicts, such as predation and transmission of diseases. Environmental challenges included the need to halt biodiversity loss and soil degradation. 
Innovations identified and selected by stakeholders: individual and group discussion

The ten SGs discussed, identified and selected potential innovations which were grouped into the four groups mentioned above (Table 3; see also Supplementary Tables S2a to S2i for details by SG). The number of proposed innovative solutions ranged from more than ten in Spanish, Hungarian and Romanian SGs, whilst five solutions were proposed by Italian and British SGs (Figure 4). The majority of solutions fell into the management and socio-economic, rather than the production and environmental categories. Generally, there was a mismatch between the number of challenges and number of solutions proposed, with fewer solutions than the number of challenges in most categories. In the case of the socio-economic category in Romania, the production category in Italy, and the environment category in Hungary and the UK, the SGs did not identify a potential solution to the identified challenges. By contrast, in the management category in Romania and Hungary, the SGs proposed a higher number of solutions than the challenges found.

Table 3. List of innovations proposed and prioritized by stakeholders groups.

\begin{tabular}{|c|c|}
\hline Experimental topic & Specific experimental work \\
\hline $\begin{array}{l}\text { System } \\
\text { design/management: } \\
\text { refers to conservation of } \\
\text { specific elements, as } \\
\text { native species, veteran } \\
\text { trees, reintroduction of } \\
\text { formerly used species, } \\
\text { hedges and windbreaks } \\
\text { conservation and/or } \\
\text { rejuvenation }\end{array}$ & $\begin{array}{l}\text { Shifting from single model of novel hedgerow to modular/diversified } \\
\text { adaptable design and progressive management techniques. Rebuilding } \\
\text { connections between hedgerows and scattered farms across the } \\
\text { landscape. } \\
\text { Combining crop rotation management, pasture management and } 3 \\
\text { dimensional design and management of hedgerows to avoid soil } \\
\text { erosion. } \\
\text { Renewing encroach-abandoned wood-pastures } \\
\text { Effect of different understory management options on cork } \\
\text { growth/calibre and cork quality }\end{array}$ \\
\hline $\begin{array}{l}\text { Tree regeneration: cost- } \\
\text { efficient protection of } \\
\text { regenerate }\end{array}$ & $\begin{array}{l}\text { Seeding combined with dead branch/wood, mulches (e.g., Ramial } \\
\text { Chipped Wood), thorny and/or nursery shrubs } \\
\text { Artificial thorny protectors } \\
\text { Mix of species for "auto-protection }\end{array}$ \\
\hline $\begin{array}{l}\text { Livestock management: } \\
\text { cost-efficient herding, } \\
\text { optimisation of fodder } \\
\text { resources use, and } \\
\text { halting system } \\
\text { degradation }\end{array}$ & $\begin{array}{l}\text { Viability and cost-effectiveness of "invisible fencing" } \\
\text { GPS collar, equipped or not with negative-stimuli devices } \\
\text { Holistic or grazing (intensive fast-rotational grazing) to improve soil and } \\
\text { pasture quality and protect tree regeneration } \\
\text { Effects of grazing exclusion on the vegetation structure, biodiversity and } \\
\text { wildfire }\end{array}$ \\
\hline Fodder resources & $\begin{array}{l}\text { Selection of species/varieties of legume pastures adapted to shade and } \\
\text { tree competition } \\
\text { Selection of double-cropped winter-forages (e.g. Triticale) adapted to } \\
\text { shade and tree competition }\end{array}$ \\
\hline New products & $\begin{array}{l}\text { Questionnaire to assess the willingness to pay a premium price for } \\
\text { different AF products (e.g. acorn-derived products) and services (e.g., } \\
\text { biodiversity, historical/aesthetic landscapes). } \\
\text { Questionnaire to identify mechanisms to promote efficient marketing of } \\
\text { AF products (e.g. human consumption of acorns in different products) }\end{array}$ \\
\hline Conservation & $\begin{array}{l}\text { Ramial wood chips and other organic mulch } \\
\text { Adoption of optimal livestock species in wood-pastures to halt soil } \\
\text { degradation and to reinforce biodiversity } \\
\text { Testing the openness of local communities to value/protect ancient trees } \\
\text { on WP }\end{array}$ \\
\hline Governance & $\begin{array}{l}\text { Favouring the design (and diffusion) of a model of cooperative (e.g. skills } \\
\text { and machines pool) for re-developing HNCV agroforestry }\end{array}$ \\
\hline
\end{tabular}




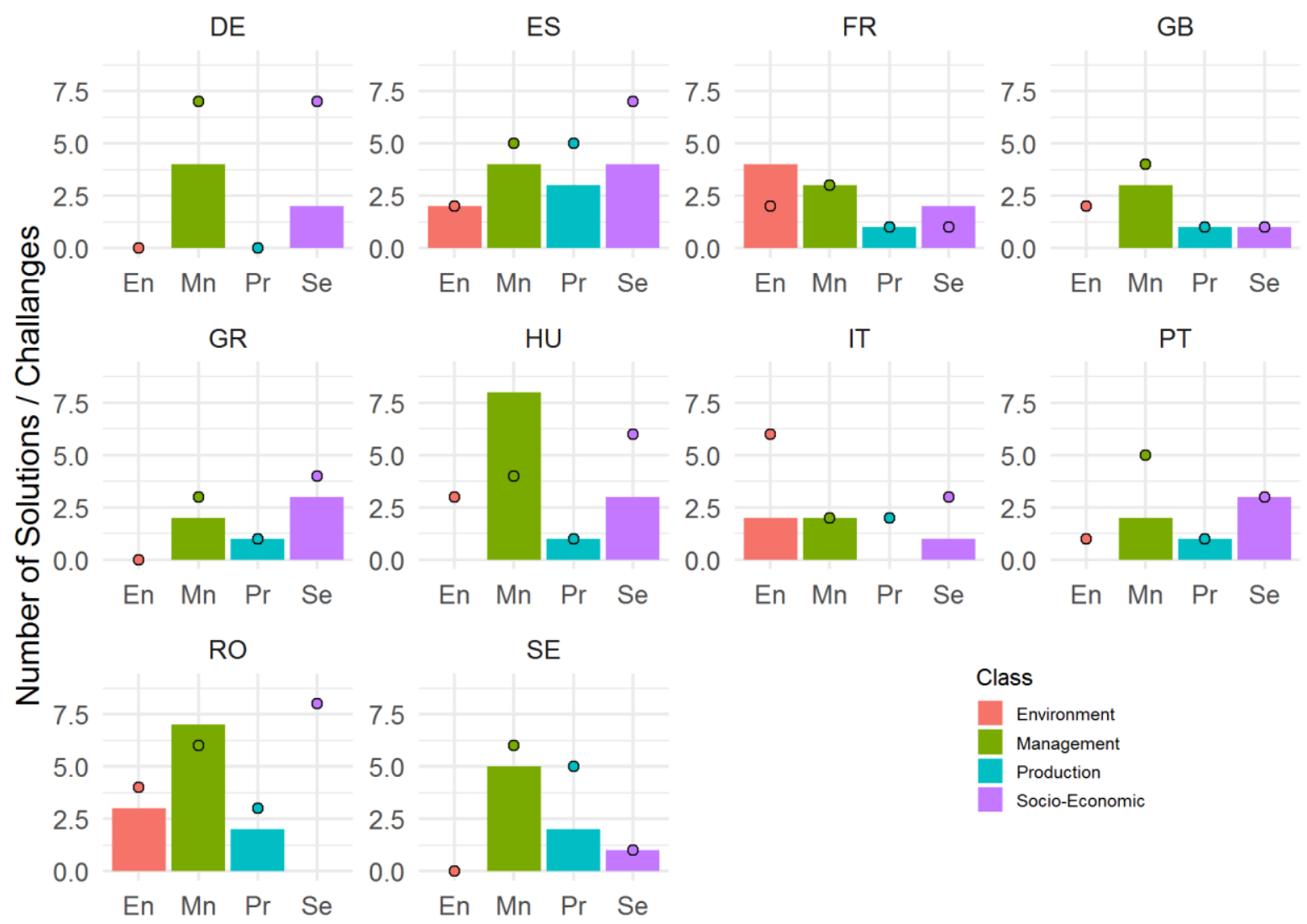

Figure 4. Number of solutions proposed for each country and category. Points depict the number of challenges identified in each country and category.

Only a few management and socio-economic innovations were common among the SGs (Figure 3), indicating that most proposed solutions were restricted to a local scale. There was common agreement on some of the innovations related to tree protection, system design and grazing schemes. A wide range of methods for more cost-effective protection of tree saplings from livestock were proposed including shelters made of woody debris, thorny and/or nursery shrubs, artificial thorny protectors, visual deterrents, chemical organic repellents, and innovative fencing systems using inexpensive RFID (radio-frequency identification) tags and sensors worn by cattle. GPS devices were proposed for cost efficient herding, for reducing contagious diseases from wildlife by providing livestock with exclusive access to watering points and supplementary food, to control livestock health (by automatic analysis of movements), and for precision-herding. "Invisible fencing" of grazing areas, which incorporates a buried loop of insulated wire that interacts with a collar fitted to each animal, was also proposed. 
Three innovations related to the improvement of system's design and management were mentioned. First, Swedish boreal forests have often only been managed for timber production. A proposed innovation was to develop a consultative process for long-term planning between foresters and the Sami people (who manage reindeer in the same forests) to enable better reindeer movement and herd control. Secondly, Portuguese, Hungarian, and German SGs proposed innovative designs for $\mathrm{HNCV}$ agroforestry that include the use of new tree species either to resist livestock damage or rejuvenate windbreaks and abandoned wood-pastures. The third innovation was proposed by the French SG, where there was an interest in moving to more diversified forms of hedgerow structure and management that would reconnect hedgerows and deliver more ecosystem services across the bocage landscape, in line with local requirements and farmers' priorities.

Innovations to increase the efficiency of the use of local forage resources included holistic grazing (intensive fast-rotational grazing), the optimization of the location of facilities (e.g. watering points, supplementary fodder, salt) and the selection of specific livestock breeds (e.g. cattle and buffalo in Romania). A potential innovation for increasing pasture productivity and quality and for ensuring a better seasonal distribution of forage resources included the use of legume-rich pastures and fodder crops such as triticale and/or ryegrasses (hay/silage, grazing, double use) adapted to shade and tree competition.

Two types of innovation were identified to increase profitability; the branding of HNCV agroforestry products and the diversification of products. The creation of an agroforestry brand and an improved awareness by customers was identified by five SGs. For example, despite the local recognition of the cultural importance of the wood-pastures in Romania, there was no local market for their products. Determining consumers' responses to agroforestry products and services was judged important to identify (i) the potential demand for such products and services; (ii) the willingness to pay a price premium for that service, and (iii) potential marketing mechanisms. Branding was identified as the single common challenge across SGs within the socio-economic category.

\section{Discussion}

Most stakeholders from our study positively valued the natural and cultural dimensions of HNCV agroforestry in their regions but were concerned about the low profitability and future economic and ecological resilience of their systems. Responses from the ten SGs highlighted that low profitability is undermining the sustainability of these systems. To our knowledge there is no systematic evaluation of the farm profitability of HNVC agroforestry systems in Europe, with the exception of the Iberian dehesas and montados (Campos et al 2018). Whilst most HNCV agroforestry systems may use less offfarm inputs, such as fertilizers and agrochemicals, than conventional agriculture, they still incur relatively high labour costs that can threaten their economic sustainability (Campos et al. 2018), which according to stakeholder responses seems to be case of all the HNCV agroforestry systems here studied. Campos et al. (2019) reporting the results of a comprehensive analysis of commercial (timber, cork, firewood, nuts, livestock grazing, conservation forestry, hunting, residential services and private amenities) and non-commercial (fire services, free access recreation, free access mushroom, carbon, landscape conservation, threatened biodiversity and water yield) products on Spanish dehesa farms found that extended account that includes non-commercial ecosystem services multiplied by 5.4 times 
the total value of farm products. The policy challenge is to maintain livestock grazing in these HNCV agroforestry systems on the basis of joint provision of multiple public ecosystem services through stable compensation policy (Campos et al. 2018).

Stakeholders require innovative solutions to improve the sustainability of their farms and, with that, the conservation of the nature that they harbor and the valuable landscapes they create (Moreno et al. 2018). All the SGs identified multiple challenges concerning the management of HNCV agroforestry, most of them identified challenges concerning production and socio-economic issues, but only four SGs were concerned by environmental issues. Our results further support this finding by showing that most negatively rated attributes were related to management and socio-economic aspects, while the most positively rated attributes were related to environmental aspects and tree regeneration. In fact, it can be argued that a straightforward way to support the sustainability of HNCV agroforestry are policy measures to conserve the nature values of European HNV farming systems (Strohbach et al. 2015), and according to our results supporting tree regeneration practices seem critical for the conservation of environmental attributes of HNCV systems. Despite the SGs across Europe sharing many common policy challenges, the selected solutions were often site-specific, which would indicate the benefit of "bottom-up" plans and public funds to support sustainable agriculture (Toderi et al. 2017). We also observed that several SGs were unable to identify cost-effective solutions to the identified environmental and productive challenges. This mismatch points to the need of further scientific research and technological development within a framework that addresses economic and social-ecological constraints to advance innovative solutions affordable by local farmers (Partelow 2016). Although SGs did not identified solutions for every challenge, they selected sets of solutions that could be implemented at the field, farm- or landscape scale to improve the ecological and socioeconomic sustainability of HNCV agroforestry under specific socio-ecological conditions.

\section{Challenges and solutions regarding production}

New commercial products that acknowledge the high cultural and natural benefits of HNVC agroforestry, such as the well-known Iberian ham and wild pear and wild apple vinegars from temperate countries (Moreno et al. 2018), were identified by the SGs. Some stakeholders also identified the economic value of trees in terms of using surplus biomass for energy, or ramial chipped wood (Dodelin et al. 2007) and charcoal (Kimetu and Lehmann 2010) for mulching. Renewed uses of acorns to feed livestock and humans (e.g. gluten-free flours, Molavi et al. 2015, and cookies from acorn flour, Pantera at al. 2018b) and oils rich in unsaturated fatty-acids (Charef et al. 2008) and tannins for leather and antioxidant uses (Onem et al. 2014; Abdalla et al. 2015, Pantera et al. 2018b) were also highlighted. In Hungary, formerly abandoned areas are being farmed again as wood-pastures to meet the demand of organic and high quality foods (Dénes et al. 2013). In Sweden forest plans of boreal forest management are being adapted to support reindeer husbandry (Horstkotte et al. 2018).

Deriving financial benefit from the aesthetic and cultural value of HNCV agroforestry landscapes is a challenge, but several initiatives were identified which help to address this. In the UK, the City of London Corporation which manages Epping Forest, and the associated livestock grazing, uses income from elsewhere to enable conservation and open access to the public that has an economic value that is substantially greater than any livestock products. Elsewhere in the UK, charities such as the 
National Trust charge membership or entrance fees for the public to access properties and estates that often have a parkland landscape, with the fees partly used to sustain the management of such ecosystems. In the Romanian case study, there have been ecotourism initiatives linking several villages to tourist routes that recognize the value of ancient wood-pasture systems. For example, the village of Mercheasa has attracted hundreds of visitors by highlighting the cultural importance of one of the largest ancient oak wood-pasture in lowland Europe (i.e. over 1000 hectares and over 400 ancient oak trees). In Greece, there are ongoing attempts to draw eco-touristic interest to oak valonia forests, but so far the additional income has been lower than the investment in the initiatives. Besides, the literature has recently reported many examples where tourism has become an outstanding economic activity in silvopastoral territories of high nature and cultural value through positive interactions among livestock farmers and other actors. Some examples are the Sami community in Sweden (Leu et al. 2018), extensive livestock farms in Mediterranean silvopastures of Sardinia and Creta islands (Farinella et al. 2017) or transhumance landscape heritage in Spain (AmatMontesinos 2017). Market distinction, collective organization, and short supply chains have been identified as important strategies to meet new demand for high-value local food and for local tourism development (Beudou et al. 2017; Berriec-Solliet et al. 2018). Nevertheless, diversifying onfarm incomes is not risk-free, and various skills are required for farmers to make a successful endeavor (McElwee and Bosworth 2010). In this regard, Genovese et al. (2017) pointed out that a concrete and sustainable innovation in the traditional business model need to be supported by the proactive intervention of a supra-farm dimension, while maintaining the peculiarities of the individual farms. Across the sites studied, there remains a need for better branding of products so that consumers are aware of the nature and cultural benefits of agroforestry and a fair share of additional revenue generated by tourists and others can be used to supporting the management of HNCV agroforestry. The greater integration of the social and environmental value of HNCV agroforestry into marketable products and services would help ensure that both the benefits and the costs can be realized and shared.

\section{Challenges and solutions regarding management}

The SGs were generally able identify innovations to address specific management challenges, probably because they could draw on their actual experiences of work already being undertaken. For instance, managers of some HNCV silvopastoral systems are introducing invisible fencing and GPS-based innovative tools that reduce the cost or increase the effectiveness of livestock herding (Markus et al. 2014; Umstatter et al. 2015, Muminov et al. 2016). However the development of lower-cost and lower energy-consuming devices is still required. These technologies can also help protect specific habitats whilst minimising the effect on wildlife. However in places like Hungary and Romania, the most cost effective strategies are still the use of herders that use traditional knowledge about livestock management to enhance nature conservation (Molnar et al. 2016).

The lack of tree regeneration was recognized as an important challenge for the sustainability of HNCV agroforestry by many groups. One proposed solution was the use of artificial wire thorny shelters and natural protectors built from pruned branches or living thorny shrubs. The use of nurse shrubs also seems a promising option (Gómez-Aparicio 2009) but further research is needed to disentangle environmental, management and productive effects (Rolo et al. 2013). Experiences in grazed wood- 
pastures in Romania (Hartel et al. 2014) suggests that effective tree regeneration initiatives need to be strongly embedded in the local social and institutional context. Some pasture owners and pasture management associations in Romania have started to recognize the value of scattered trees for livestock and the overall pasture environment. For example, initiatives have been launched to assist tree regeneration by using the facilitative role of thorny shrubs for example on the Cobor Farm in Romania (Hartel personal experience as collaborator). In some situations, it is necessary to engage with and secure support from local stakeholders beyond the immediate farmer, as many farmers are unable to fund the practices that favor tree regeneration because the low return from their grazing activities.

Grazing can substantially reduce the risk of wildfire in Mediterranean silvopastoral landscapes (Rigueiro-Rodríguez et al. 2005; Silva and Catris et al. 2006; Franca et al. 2012; Damianidis et al. 2020). However, to effectively provide this important ecosystem service, a multi-actor program implemented at landscape scales is typically needed. For instance, in Southern Spain, the RAPCA program (Network of Firebreak Areas Managed with Grazing) works with 222 shepherds that graze 6690 hectares of wood-pastures with 78,000 sheep, 17,000 goats and 1,200 cattle to reduce wildfire risk in $>100000$ ha of Andalusian forests (Varela et al. 2018).

\section{Challenges and solutions regarding the conservation of nature and cultural values}

Although the natural and cultural values of the agroforestry systems are generally acknowledged by stakeholders, their long-term sustainability can still be improved by encouraging positive attitude of local communities towards their HNCV agroforestry systems. These initiatives should take into account the specificities of each local community. In this line, for instance, our results showed that environmental challenges were more important in the Italian SG than in Spanish and Portuguese SGs. This finding highlights the potential differences among local communities, despite sharing a potentially similar background. In traditional wood-pasture agroforestry systems, there is also a need, at the level of the local communities, to increase the recognition and appreciation of ancient trees (Hartel et al. 2017). In Romania, several measures were initiated in the past decade to promote the social-ecological values of wood-pastures in Southern Transylvania. These measures include i) involving local communities in the preservation and valuing of the ancient trees and wood-pastures, ii) protecting 85,000 hectares of wood-pastures as Natura 2000 sites, iii) collectivizing the market of traditional milk-based products and motivating farmers to use their wood-pastures, and iv) using education and awareness. Example education and awareness projects include "The Remarkable Trees of Romania", "Find the oldest tree", "One oakfor every pupil", and old tree artistic events to popularize ancient trees (Hartel et al. 2016). Still, a recent study implemented in a pastoral area with the some of the most ancient oak wood-pastures within Central and Eastern Europe suggested that local people still do not recognise the cultural, historical and legacy values of ancient oaks (Torralba et al. 2018). This highlights the continued need to improve the communication of the multiple values and opportunities of these agroforestry systems to local communities.

An awareness of the conservation value of grazed and pollarded woodlands has led to the reintroduction of pollarding and grazing activities at the case study site in the UK. In Western Greece, various NGOs are also supporting the regeneration of valonia oak by replanting which suggests an 
optimism future for such systems. A plan for the rejuvenation of the abandoned hedgerows in the German Spreewald floodplain (called "Spreewald Grassland Shares") aims to stimulate public involvement in maintaining this traditional landscape. In the bocage system in Brittany in France, new hedge planting schemes have been implemented since the 1990s. The objectives in hedgerow planting include the maintenance of the cultural landscape and the regulation of nitrate and phosphorus pollution. In both Germany and France, the use of tree biomass is also viewed as a renewed opportunity for farmers. For instance, in the German Spreewald floodplain, an increased value placed on biomass is allowing the re-opening of excessively thickened wood-pastures.

\section{Conclusions}

In spite of numerous ecological and economic benefits described for agroforestry systems, numerous studies highlight the difficulty in conserving traditional HNCV agroforestry and adopting new innovative forms of agroforestry across the world (Matthews et al. 1993; Udawatta and Godsey 2010; Coe et al. 2014). One possible reason for this is the low engagement between appropriate local stakeholders and high-level institutions (Cavender-Bares et al. 2015; Dumont et al. 2019). Here we have used a standardized participatory approach to assess across Europe the benefits and disadvantages of HNCV agroforestry perceived by local stakeholder groups. At the same time, stakeholder groups selected possible cost-effective innovations to address a range of challenges. Although the challenge categories were common across countries, the proposed innovations were typically more locally focused. This highlights the need to integrate local famers with other actors with different interests and territorial focus in the process of developing innovative solutions.

Innovations and research on the best agroforestry design and management practices to deliver the most valuable products and public services are still needed. Surprisingly, few products are marketed as products of HNCV agroforestry, even though some consumers are willing to pay for high quality and environmentally-beneficial products. Hence, better branding is identified as one solution to improve the sustainability of these systems. Further support to specific commercialization strategies could provide an added value to the high variety of products from HNCV agroforestry in order to alleviate their profitability problems. Given the low level of agricultural production per unit area of many of the systems, it is also important for the farmers and managers to derive financial advantage from the high nature and cultural value of these systems. Hence although labelling and branding have a role, local and national governments should also support the sustainability of HNCV agroforestry by placing a monetary value on public cultural benefits. The stakeholder groups were generally unable to identify many innovations to address the socio-economic challenges, which suggests that more research is needed in this area. A systematic evaluation of the technical and cost-effectiveness of socio-economic innovations to support European HNVC agroforestry could bridge this gap and identify actions for policy makers to adopt.

Agroforestry can help farmers to address many of the targets in current agricultural policies, there are experienced stakeholders on the ground who are ready to take action, and there is increasing shared awareness of the innovations that can work. As a matter of fair social and environmental approach, the challenge for policy makers, working with stakeholders including researchers, is to create a policy 
and financial framework that brings together these components so that HNVC agroforestry can deliver profitable and healthy food and the enhanced delivery of natural and cultural services to wider society.

\section{Acknowledgments}

AGFORWARD project (Grant Agreement $N^{\circ} 613520$ ), funded by 7th Framework Programme of RTD of the European Commission. We thank the 230 stakeholders who participated in the study for sharing their insights. V. Rolo was supported by a "Talento" fellowship (TA18022) funded by the regional government of Extremadura (Spain).

\section{References}

Abdalla S, Pizzi A, Bahabri F, Ganash A (2015) Analysis of valonia oak (Quercus aegylops) acorn tannin and wood adhesives application. BioResources 10:7165-7177

Amat-Montesinos X (2017) Landscape and heritage of the transhumance in Spain. Challenges for a sustainable and responsible tourism. In: Innovations sociales en tourisme, en patrimonie et dans les musées, Savoirs Canadiens, Espagnoles et d'ailleurs, 11-12 Mai 2017, Université Laval, Quebex, Canada.

Andersen E, Baldock D, Bennet H, Beaufoy G, Bignal E, Brower F, Elbersen B, Eiden G, Godeschalk F, Jones G, McCracken DI, Nieuwenhuizen W, van Eupen M, Hennekes S, and Zervas G (2003). Developing a high nature value farming area indicator. Consultancy report to the EEA. European Environment Agency, Copenhagen.

Archer SR (2010) Rangeland conservation and shrub encroachment: new perspectives on an old problem. In: Toit, J.T. d. Kock, R. Deutsch, J.C. (eds.) Wild Rangelands: Conserving Wildlife While Maintaining Livestock in Semi-Arid Ecosystems. pp 53-97.

Aubard V, Paulo JA, Silva JMN (2019) Long-term monitoring of cork and holm oak stands productivity in Portugal with Landsat imagery. Remote Sensing 11:525. DOI 10.3390/rs11050525

Bergmeier E, Petermann J, Schröder E (2010) Geobotanical survey of wood-pasture habitats in Europe: diversity, threats and conservation. Biodivers Conserv 19(11):2995-3014

Berriet-Solliec M, Lataste F, Lépicier D, Piguet V (2018) Environmentally and socially beneficial outcomes produced by agro-pastoral systems in the Cévennes National Park (France). Land Use Policy 78:739-747

Beudou J, Martin G, Ryschawy J (2017) Cultural and territorial vitality services play a key role in livestock agroecological transition in France. Agron Sustain Dev 37(4):36

Bignal EM, McCracken DI (2000).The nature conservation value of European traditional farming systems. Environmental reviews 8, 149-171. DOI 10.1139/a00-009

Bugalho MN, Caldeira MC, Pereira JS, Aronson J, Pausas JG (2011) Mediterranean cork oak savannas require human use to sustain biodiversity and ecosystem services. Frontiers in Ecology and the Environment 9: 278-286. DOI 10.1890/100084

Burgess PJ, Rosati A (2018) Advances in European agroforestry: results from the AGFORWARD project. Agroforestry Systems 92: 801-810. DOI 10.1007/s10457-018-0261-3

Butler J, Alexander K, Green T (2002). Decaying wood: an overview of its status and ecology in the United Kingdom and Continental Europe. USDA For. Serv. Gen. Tech. Rep. PSW-GTR-181, 11-19.

Calama R, Tomé M, Sánchez-González M, Miina J, Spanos K, Palahi M (2010). Modelling Non-Wood Forest Products in Europe: a review. Forest systems 19: 69-85.

Campos P, Ovando P, Mesa B, Oviedo JL (2018) Environmental income of livestock grazing on privatelyowned silvopastoral farms in Andalusia, Spain. Land Degrad Dev 29:250-261. https ://doi.org/10.1002/ldr.2529

Campos P, Caparrós A, Oviedo JL, Ovando P, Álvarez-Farizo B, Díaz-Balteiro L, Carranza J, Begueria S, Diaz M, Herruzo AC, Martínez-Peña F, Solino M, Álvarez A, Martínez-Jauregui M, PasadolosTatos $\mathrm{M}$, de Frutos $\mathrm{P}$, Aldea J, Almazán E, Concepción ED, Mesa B, Romero C, Serrano-Notivoli 
R, Fernández C, Torres-Porras J, Montero G (2019) Bridging the gap between national and ecosystem accounting application in Andalusian Forests, Spain. Ecol Econ 157:218-236. https ://doi.org/10.1016/j.ecole con.2018.11.017

Cavender-Bares J, Polasky S, King E, Balvanera P (2015) A sustainability framework for assessing tradeoffs in ecosystem services. Ecology and Society 20: 17. DOI 10.5751/ES-06917-200117

Charef M, Yousfi M, Saidi M, Stocker P (2008) Determination of the fatty acid composition of acorn (Quercus), Pistacia lentiscus seeds growing in Algeria. Journal of the American Oil Chemists' Society 85: 921-924. DOI 10.1007/s11746-008-1283-1

Coe R, Sinclair F, Barrios E (2014) Scaling up agroforestry requires research 'in'rather than 'for'development. Current Opinion in Environmental Sustainability 6: 73-77. DOI 10.1016/j.cosust.2013.10.013

Damianidis C, Santiago-Freijanes JJ, den Herder M, Burgess PJ, Mosquera Losada MR, Graves A, Papadopoulos A, Pisanelli A, Camilli F, Rois-Díaz M, Kay S, Palma JHN, Pantera A (2020) Agroforestry as a sustainable land use option to reduce wildfires risk in European Mediterranean areas. Agroforestry Systems. DOI 10.1007/s10457-020-00482-w

den Herder M, Moreno G, Mosquera-Losada RM, Palma JHN, Sidiropoulou A, Santiago Freijanes JJ, Crous-Duran J, Paulo JA, Tomé T, Pantera A, Papanastasis VP, Mantzanas K, Pachana P, Papadopoulos A, Plieninger T, Burgess PJ (2017) Current extent and stratification of agroforestry in the European Union. Agriculture, Ecosystems and Environment 241: 121-132. DOI: 10.1016/j.agee.2017.03.005

Dénes, S., Anna, V., Károly, P., Ákos, M., \& Tamás, S. (2013). Agrosilvopastoral systems and possibilities of application in organic farming in Hungary. Animal Welfare, Ethology and Housing Systems, 9(3, Suppl. 1), 315-320.

Dodelin B, Eynard-Machet R, Athanaze PJA (eds.) (2007) Les Rémanents en Foresterie et Agriculture Les Branches : Matériau d'Avenir. Proceedings of the international conference held in Lyon, France, on 1-2/02/2007. Tec \& Doc, Hermès-Lavoisier, Paris, 384 p.

Dumont ES, Bonhomme S, Pagella TF, Sinclair FL (2019) Structured stakeholder engagement leads to development of more diverse and inclusive agroforestry options. Experimental Agriculture 55: 252-274. DOI 10.1017/S0014479716000788

Eldridge DJ, Bowker MA, Maestre FT, Roger E, Reynolds JF, Whitford W G (2011) Impacts of shrub encroachment on ecosystem structure and functioning: towards a global synthesis. Ecology Letters 14: 709-722. DOI 10.1111/j.1461-0248.2011.01630.x

Faias SP, Paulo JA, Palma JHN, Tomé M (2018) Understory effect on tree and cork growth in cork oak woodlands. Forest Systems 27: e02S. DOI 10.5424/fs/2018271-11967

Franca A, Sanna F, Nieddu S, Re GA, Pintus GV, Ventura A, Duce P, Salis M, Arca B (2012) Effects of grazing on the traits of a potential fire in a Sardinian wooded pasture. In: New approaches for grassland research in a context of climate and socio-economic changes. Eds. Acar Z., LópezFrancos A., Porqueddu C. Options Méditerranéennes : Série A. Séminaires Méditerranéens; n. 102, Zaragoza : CIHEAM, pp 307-311.

García de Jalón S, Burgess PJ, Graves A, Moreno G, McAdam J, Pottier E, Novak S, Bondesan V, Mosquera-Losada R, Crous-Durán J, Palma JHN, Paulo JA, Oliveira TS, Cirou E, Hannachi $Y$, Pantera A, Wartelle R, Kay S, Malignier N, Van Lerberghe P, Tsonkova P, Mirck J, Rois M, Kongsted AG, Thenail C, Luske B, Berg S, Gosme M, Vityi A. 2018. How is agroforestry perceived in Europe? An assessment of positive and negative aspects by stakeholders. Agroforestry Systems 92, 829-848. DOI 10.1007/s10457-017-0116-3

Genovese D, Culasso F, Giacosa E, Battaglini LM (2017) Can livestock farming and tourism coexist in mountain regions? A new business model for sustainability. Sustainability 9(11):2021

Gómez-Aparicio L (2009) The role of plant interactions in the restoration of degraded ecosystems: a meta-analysis across life-forms and ecosystems. Journal of Ecology 97: 1202-1214. DOI 10.1111/j.1365-2745.2009.01573.x 
Gómez-Rey MX, Madeira M, Gonzalez-Prieto SJ, Coutinho J (2013) Soil C and N dynamics in a Mediterranean oak woodland with shrub encroachment. Plant Soil 371: 339-354. DOI 10.1007/s11104-013-1695-z

Hartel T, Plieninger T (2014) European wood-pastures in transition: a social-ecological approach. Routledge, Abingdon, p 302

Hartel T, Dorresteijn I, Klein C, Máthé O, Moga Cl, Öllerer K, Roellig M, Wehrden H, Fischer J. (2013). Wood-pastures in a traditional rural region of Eastern Europe: Characteristics, management and status. Biological Conservation 166: 267-275. DOI 10.1016/j.biocon.2013.06.020

Hartel T, Fischer J, Câmpeanu C, Milcu Al, Hanspach J, Fazey I (2014) The importance of ecosystem services for rural inhabitants in a changing cultural landscape in Romania. Ecology and Society 19: 42. DOI 10.5751/ES-06333-190242

Hartel T, Olga Réti K, Craioveanu C, Gallé R, Popa R, Ioniţă A, Demeter L, Rákosy L, Czúcz B (2016) Rural social-ecological systems navigating institutional transitions: case study from Transylvania (Romania). Ecosystem Health and Sustainability 2: e01206. DOI 10.1002/ehs2.1206

Hartel T, Réti KO, Craioveanu C (2017) Valuing scattered trees from wood-pastures by farmers in a traditional rural region of Eastern Europe. Agriculture, Ecosystems \& Environment 236: 304311. DOI 10.1016/j.agee.2016.11.019

Hernández-Morcillo M, Burgess P, Mirck J, Pantera A, Plieninger T (2018) Scanning agroforestry-based solutions for climate change mitigation and adaptation in Europe. Environmental Science \& Policy 80, 44-52. DOI 10.1016/j.envsci.2017.11.013

Horstkotte, T., Lind, T., \& Moen, J. (2016). Quantifying the implications of different land users' priorities in the management of boreal multiple-use forests. Environmental management, 57(4), 770-783.

Jose S (2009). Agroforestry for ecosystem services and environmental benefits: an overview. Agroforestry Systems 76:1-10. DOI 10.1007/s10457-009-9229-7

Kay S, Graves A, Palma JH, Moreno G, Roces-Díaz JV, Aviron S, Chouvardas D, Crous-Duran J, FerreiroDomínguez N, García de Jalón S, Măcicăşan V, Mosquera-Losada MR, Pantera A, SantiagoFreijanes JJ, Szerencsits E, Torralba M, Burgess PJ, Herzog F (2019) Agroforestry is paying offEconomic evaluation of ecosystem services in European landscapes with and without agroforestry systems. Ecosystem Services 36: 100896. DOI 10.1016/j.ecoser.2019.100896

Kimetu JM, Lehmann J (2010) Stability and stabilisation of biochar and green manure in soil with different organic carbon contents. Soil Research 48: 577-585. DOI 10.1071/SR10036

Kremen, C., \& Merenlender, A. M. (2018). Landscapes that work for biodiversity and people. Science, 362(6412), eaau6020. DOI 10.1126/science.aau6020

Leu TC, Eriksson M, Müller DK (2018) More than just a job: exploring the meanings of tourism work among Indigenous Sámi tourist entrepreneurs. J Sustain Tour 26(8):1468-1482

Lomba A, Moreira F, Klimek S et al (2020) Back to the future: rethinking socioecological systems underlying high nature value farmlands. Front Ecol Environ 18:36-42. https ://doi.org/10.1002/fee.2116

Manning A, Fischer J, Lindnmayer D (2006) Scattered trees are keystone structures - Implications for conservation. Biological Conservation 132: 311-321. DOI 10.1016/j.biocon.2006.04.023

Markus SB, Bailey DW, Jensen D (2014) Comparison of electric fence and a simulated fenceless control system on cattle movements. Livestock Science 170: 203-209. DOI 10.1016/j.livsci.2014.10.011

McElwee G, Bosworth G (2010) Exploring the strategic skills of farmers across a typology of farm diversification approaches. J.Farm Manag 13:819-838

Matthews S, Pease SM, Gordon AM, Williams PA (1993) Landowner perceptions and the adoption of agroforestry practices in southern Ontario, Canada. Agroforestry Systems 21: 159-168. DOI 10.1007/BF00705227

Molavi H, Keramat J, Raisee B (2015) Evaluation of the Cake Quality Made from Acorn-Wheat Flour Blends as a Functional Food. Journal of Food Biosciences and Technology 5: 53-60. 
Molnár Zs, Kis J, Vadász Cs, Papp L, Sándor I, Béres S, Sinka G, Varga A (2016) Common and conflicting objectives and practices of herders and nature conservation managers: the need for the 'conservation herder'. Ecosystem Health and Sustainability 2: e01215. DOI 10.1002/ehs2.1215

Moreno G, Pulido P (2009) The functioning, management and persistence of Dehesas. In: RigueiroRodriguez, A. McAdam, J. Mosquera-Losada, M.R. (eds.) Agroforestry in Europe, Current Status and Future Prospects, Advances in Agroforestry, 6: 127-160. Springer, Heidelberg. DOI 10.1007/978-1-4020-8272-6_7

Moreno G, Aviron S, Berg S, Crous-Durán J, Franca F, García de Jalón S, Hartel T, Mirck J, Pantera A, Palma JHN, Paulo JA, Re GA, Sanna F, Thenail C, Varga A, Viaud V, Burgess PJ (2018) Agroforestry systems of high nature and cultural value in Europe: provision of commercial goods and other ecosystem services. Agroforestry Systems 92: 877-891. DOI 10.1007/s10457-017-0126-1

Muminov A, Na D, Lee C, Jeon HS (2016). Virtual fences for controlling livestock using satellite-tracking and warning signals. International Conference on Information Science and Communications Technologies (ICISCT), IEEE, pp. 1-7. DOI 10.1109/ICISCT.2016.7777385

Onem E, Gulumser G, Akay S, Yesil-Celiktas O (2014) Optimization of tannin isolation from acorn and application in leather processing. Industrial Crops and Products 53: 16-22. DOI 10.1016/j.indcrop.2013.12.014

Pantera, A., Papadopoulos, A. \& Papanastasis, V.P. Valonia oak agroforestry systems in Greece: an overview. Agroforest Syst 92, 921-931 (2018). DOI 10.1007/s10457-018-0220-z

Pantera, A., Burgess, P.J., Mosquera Losada, R. et al. Agroforestry for high value tree systems in Europe. Agroforest Syst 92, 945-959 (2018). DOI 10.1007/s10457-017-0181-7

Paracchini ML, Petersen J-E, Hoogeveen Y, Bamps C, Burfield I, van Swaay C (2008): High Nature Value Farmland in Europe - An estimate of the distribution patterns on the basis of land cover and biodiversity data. JRC EEA, Report EUR 23480 EN. 87 pp. DOI 10.2788/8891

Partelow S (2016) Coevolving Ostrom's social-ecological systems (SES) framework and sustainability science: four key co-benefits. Sustainability Science 11: 399-410. DOI 10.1007/s11625-0150351-3

Paulo JA, Faias SP, Ventura-Giroux C, Tomé M (2015) Estimation of stand crown cover using a generalized crown diameter model: application for the analysis of Portuguese cork oak stands stocking evolution. iForest. DOI 10.3832/ifor1624-008

Pereira HM, Domingos T, Vicente L (eds.) (2004) Portugal Millennium Ecosystem Assessment: State of the Assessment Report. Centro de Biologia Ambiental de la Faculdade de Ciências, Universidade de Lisboa,68.

Plieninger T, Hartel T, Martín-López B, Beaufoy G, Bergmeier E, Kirby K, Montero MJ, Moreno G, Oteros-Rozas E, Van Uytvanck J (2015) Wood-pastures of Europe: Geographic coverage, socialecological values, conservation management, and policy implications. Biological Conservation 190: 70-79. 10.1016/j.biocon.2015.05.014

Plieninger T, Wilbrand C (2001) Land use, biodiversity conservation, and rural development in the dehesas of Cuatro Lugares, Spain. Agroforestry Systems 51: 23-34. DOI 10.1023/A:1006462104555

Pulido F, García E, Obrador JJ, Moreno G (2010) Multiple pathways for tree regeneration in anthropogenic savannas: incorporating biotic and abiotic drivers into management schemes. J Appl Ecol 47(6):1272-1281

Rigueiro-Rodríguez A, Mosquera Losada MR, Romero Franco R, González Hernández MP, Villarino Urtiaga JJ (2005) Silvopastoral systems as a forest fire prevention technique. In: Silvopastoralism and sustainable land management. Proceedings of an international congress on silvopastoralism and sustainable management. Eds. Mosquera-Losada, M. R., RigueiroRodríguez, A., McAdam, J. Lugo, Spain, April 2004. DOI 10.1079/9781845930011.0380

Rolo V, Plieninger T, Moreno G (2013) Facilitation of holm oak recruitment through two contrasted shrubs species in Mediterranean grazed woodlands: Patterns and processes. Journal of Vegetation Science 24: 344-355. DOI 10.1111/j.1654-1103.2012.01458.x 
Rossetti I, Bagella S (2014) Mediterranean Quercus suber wooded grasslands risk disappearance: New evidences from Sardinia (Italy). Forest Ecology and Management 329: 148-157. DOI 10.1016/j.foreco.2014.06.010

Silva JS, Catry F (2006) Forest fires in cork oak (Quercus suber L.) stands in Portugal. International Journal of Environmental Studies 63: 235-257. DOI 10.1080/00207230600720829

Strohbach MW, Kohler ML, Dauber J, Klimek S (2015) High nature value farming: from indication to conservation. Ecological indicators 57: 557-563. DOI 10.1016/j.ecolind.2015.05.021

Toderi M, Francioni M, Seddaiu G, Roggero PP, Trozzo L, D'Ottavio P (2017) Bottom-up design process of agri-environmental measures at a landscape scale: Evidence from case studies on biodiversity conservation and water protection. Land use policy 68: 295-305. DOI 10.1016/j.landusepol.2017.08.002

Torralba M, Fagerholm N, Burgess PJ, Moreno G, Plieninger T (2016) Do European agroforestry systems enhance biodiversity and ecosystem services? A meta-analysis. Agriculture, Ecosystems \& Environment 230: 150-161. DOI 10.1016/j.agee.2016.06.002

Udawatta RP, Godsey LD (2010) Agroforestry comes of age: putting science into practice. Agroforestry systems 79: 1-4. DOI 10.1007/s10457-010-9296-9

Umstatter C, Morgan-Davies J, Waterhouse T (2015) Cattle responses to a type of virtual fence. Rangeland Ecology \& Management 68: 100-107. DOI 10.1016/j.rama.2014.12.004

Valinger E, Berg S, Lind T (2018) Reindeer husbandry in a mountain Sami village in boreal Sweden: the social and economic effect of introducing GPS collars and adaptive forest management. Agroforestry Systems 92:, 933-943. DOI 10.1007/s10457-018-0249-z

Varela E, Górriz-Mifsud E, Ruiz-Mirazo, J, López-i-Gelats F (2018) Payment for Targeted Grazing: Integrating Local Shepherds into Wildfire Prevention. Forests 9: 464. DOI 10.3390/f9080464

Villamor GB, Palomo I, Santiago CAL, Oteros-Rozas E, Hill J (2014) Assessing stakeholders' perceptions and values towards social-ecological systems using participatory methods. Ecological Processes 3, 22. DOI 10.1186/s13717-014-0022-9 